\title{
Kajian reflektif: Relevansi pendidikan humanis-religius dalam menghadapi era revolusi industri 4.0
}

\author{
Rohmatun Lulkuk Isnaini * \\ Program Studi Pendidikan Bahasa Arab, Universtas Islam Negeri (UIN) Sunan Kalijaga Yogyakarta. \\ Jalan Laksda Adisucipto, Caturtunggal, Depok, Sleman, Yogyakarta 55281, Indonesia. \\ rohmatun.isnaini@uin-suka.ac.id \\ * Corresponding Author
}

\section{ARTICLE INFO}

\section{Article History \\ Received: \\ 2 September 2019; \\ Revised: \\ 11 February 2020; \\ Accepted: \\ 11 February 2020}

\section{Keywords}

Pendidikan;

Humanis;

Religius;

Revolusi industry 4.0;

Education;

Humanists;

Religious;

Industrial revolution

4.0

\begin{abstract}
ABSTRAK
Penelitian ini bertujuan untuk mengkaji pendidikan humanis-religius secara reflektif dalam menghadapi era revolusi industri 4.0. Data dikumpulkan dengan teknik library research (penelitian pustaka). Data yang telah terkumpul kemudian dianalisis secara kualitatif dengan pendekatan deskriptif. Analisis data dilakukan melalui pemaparan suatu pemikiran, pendapat para ahli (Ki Hajar Dewantara dan Prof. Abdurrahman Mas'ud, Ph.D.) atau fenomena yang ada dalam kehidupan masyarakat. Hasilnya menyebutkan bahwa pendidikan humanis-religius akan terus relevan dengan berbagai perubahan zaman, terutama dalam menghadapi era revolusi industri 4.0. Hal ini dikarenakan pendidikan humanis-religius merupakan dasar pondasi dalam kehidupan setiap insan untuk menjadikannya manusia yang berkarakter baik, tidak hanya untuk dirinya sendiri tetapi juga mampu bersikap humanis terhadap sesama dengan landasan agama. Sikap humanis dan religius akan dibutuhkan pada setiap masa oleh manusia, oleh karenanya melalui pendidikan humanis-religius akan ada keseimbangan antara kemajuan intelektual untuk sosial kemasyarakatan, sehingga dapat menghasilkan generasi-generasi yang berkarakter kuat secara humanis dan religius dengan segala potensi yang dimilikinya dan diorientasikan untuk kemashlahatan umat untuk meraih kebahagiaan bagi kehidupan.
\end{abstract}

This research aims to examine reflective humanist-religious education in the face of the industrial revolution era 4.0. Data collected by library research techniques (library research). The collected data is then analyzed qualitatively using a descriptive approach. Data analysis is carried out through the presentation of thought, opinion of experts (Ki Hajar Dewantara and Prof. Abdurrahman Mas'ud, Ph.D.) or phenomena that exist in people's lives. The results state that humanist-religious education will continue to be relevant to the changing times, especially in the face of the industrial revolution 4.0. This is because humanistreligious education is the basic foundation in the life of every human being to make him a human with good character not only for himself but also able to be humane towards others with a religious foundation. Humanist and religious attitudes will be needed at all times by humans. Therefore, through humanistreligious education, there will be a balance between intellectual progress for social society so that it can produce generations of people who have strong human and religious characteristics with all the potential they have and are oriented to the benefit of the people to achieve happiness for life.

This is an open access article under the $\underline{\mathrm{CC}-\mathrm{BY}-\mathrm{SA}}$ license.

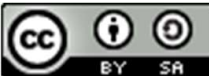




\section{PENDAHULUAN}

Menurut Rabindranath Tagore pendidikan adalah proses sosial yang berlangsung secara terus menerus dan harus dikaitkan dengan kehidupan ekonomi dan sosial masyarakat, sehingga sekolah disebut sebagai miniatur masyarakat (Samuel, 2011, p. 1166). Peningkatan kelangsungan hidup secara signifikan hanya mungkin terwujud jika pelaku pendidikan bisa memahami esensi dari belajar dan saling berbagi kasih dalam hidup. Sebagaimana perspektif pendidikan dari Ki Hajar Dewantara yang menitikberatkan pada pengajaran adab dan kesusilaan dan mengajarkan tentang segala sifat dan bentuk kebaikan dalam hidup manusia, bukan hanya untuk diketahui dan dimengerti, akan tetapi untuk diinsafi, diingini, dikehendaki, dan dilakukan oleh manusia. Pengajaran adab tersebut menekankan pada segala hak dan kewajiban manusia baik sebagai diri pribadi maupun sebagai anggota masyarakat (Dewantara, 2011, p. 483). Dengan begitu, pendidikan yang dilakukan harus dapat mendorong pemberdayaan peserta didik dalam mengapresiasi pentingnya sikap humanis agar memiliki rasa peduli dan berbagi dalam suatu masyarakat.

Tidak seharusnya pendidikan hanya berorientasi pada tujuan akhir untuk mencari pekerjaan, akan tetapi bagaimana pendidikan mengcounter pada semangat pembangunan (Guha, 2013, p. 37). Pendidikan haruslah mencerahkan, bukan hanya sekadar menghasilkan pekerja untuk pabrik-pabrik kantor semata (Samuel, 2010, p. 650). Tujuan pendidikan tidak boleh hanya terfokus untuk menghasilkan lulusan yang menguasai scientia tapi juga bertujuan untuk mencerdaskan kehidupan bangsa, serta membekali peserta didiknya dengan semangat kebangsaan, semangat keadilan sosial, serta sifatsifat kemanusiaan dan moral luhur sebagai warga negara agar dapat menjadi generasi yang siap menghadapi perubahan secara mental dan spiritual (Saksono, 2008, p. 76).

Pergeseran nilai dan tujuan dari pendidikan yang ideal terjadi di era revolusi industri 4.0. Era ini menyebabkan pasar global mengalami disrupsi. Disrupsi tidak hanya berlaku pada dunia ekonomi bisnis saja, namun fenomena disrupsi juga memberikan dampak perubahan yang besar dalam berbagai bidang, tidak terkecuali bidang pendidikan. Pendidikan dituntut adaptif dalam menanggapi perubahan yang terjadi. Perubahan yang tidak hanya dilakukan dengan sekedar mengubah cara pengajaran, tetapi jauh yang lebih esensial, yakni merubah cara pandang terhadap konsep pendidikan itu sendiri. Namun, tidak dapat dipungkiri bahwa pendidikan merupakan tempat produksi meluluskan orang-orang terdidik yang siap dalam memenuhi kualifikasi dunia kerja. Pendidikan perlu menyesuaikan diri pada situasi dimana era revolusi industri 4.0 mengubah konsep pekerjaan, struktur pekerjaan, dan kompetensi yang dibutuhkan dunia pekerjaan. Sebuah survei perusahaan perekrutan internasional, Robert Walters, bertajuk Salary Survey 2018 dalam Sukartono (2018, p. 2) menyebutkan bahwa fokus pada transformasi bisnis ke platform digital telah memicu permintaan profesional sumber daya manusia (SDM) yang memiliki kompetensi yang jauh berbeda dari sebelumnya.

Siap tidak siap tantangan pendidikan dalam menghadapi era revolusi industri 4.0 semakin berat dan menantang. Pendidikan dituntut mampu menghasilkan lulusan atau Sumber Daya Manusia (SDM) yang unggul dan kompeten. Pendidikan setidaknya harus mampu menyiapkan anak didiknya menghadapi tiga hal: 1.) Menyiapkan SDM untuk bisa bekerja yang pekerjaannya saat ini belum ada; 2.) Menyiapkan SDM untuk bisa menyelesaikan masalah yang masalahnya saat ini belum muncul; dan 3) Menyiapkan SDM untuk bisa menggunakan teknologi yang sekarang teknologinya belum ditemukan (Sukartono, 2018, p. 3). Untuk bisa menghadapi tantangan tersebut, syarat penting yang harus dipenuhi adalah bagaimana menyiapkan kualifikasi dan kompetensi guru yang berkualitas. Jack Ma mengatakan dalam pertemuan tahunan World Economic Forum 2018 bahwa pendidikan adalah tantangan besar abad ini. Jika guru tidak mengubah cara mendidik dan belajar-mengajar, 30 tahun mendatang dunia pendidikan akan mengalami kesulitan besar. Pendidikan dan pembelajaran yang sarat dengan muatan pengetahuan dan mengesampingkan muatan sikap dan keterampilan, akan menghasilkan peserta didik yang tidak mampu berkompetisi dengan mesin. Dominasi pengetahuan dalam pendidikan dan pembelajaran harus diubah agar kelak lulusan sekolah mampu mengungguli kecerdasan mesin sekaligus mampu bersikap bijak dengan memperhatikan sisi humanis-religiusnya dalam menggunakan mesin untuk kemaslahatan.

Dampak lain yang muncul di era ini adalah adanya perubahan paradigma dalam kehidupan individu yang juga memiliki efek pada sektor pendidikan. Kecenderungan sikap individualis adalah 
gejala yang tampak nyata di masyarakat. Sikap individualis pada satu sisi dapat dimaklumi sebagai cerminan kecemasan yang dialami, namun sikap ini juga mengakibatkan sikap tidak peduli kepada lingkungan dan lingkungan sosial sekitarnya (Subasman, 2019, p. 3). Pada masyarakat Indonesia yang umumnya masih mempunyai kohesifitas (kedekatan) sosial yang tinggi pada lingkungan. Hal ini mengindikasikan bahwa sikap ketidakpedulian pada lingkungan sosial dapat mengancam kehidupan sosial. Nilai-nilai sosial dan norma yang telah ada menjadi hal yang akan terancam melalui sikap yang individualis. Terkikisnya sikap-sikap humanis di masyarakat karena perubahan sikap individu merupakan keadaan yang sangat mengkhawatirkan karena nilai-nilai tersebut adalah nilai yang telah berbaur dengan nilai-nilai agama. Secara tidak langsung, keadaan tersebut akan mengurangi sikap dan perilaku masyarakat dalam menjalankan nilai-nilai keagamaan. Untuk itu, bagaimana pendidikan bisa mempertahankan dan melestarikan nilai-nilai humanis-religius agar era revolusi industri 4.0 tidak mengancam norma-norma sosial?

Pendidikan humanis-religius adalah perpaduan penerapan antara nilai humanis dan religius. Pendidikan humanis yang menekankan aspek kemerdekaan individu diintegrasikan dengan pendidikan religius agar dapat membangun kehidupan individual-sosial yang memiliki kemerdekaan, dengan tidak meninggalkan nilai-nilai keagamaan (Kuntoro, 2013). Rasa kemanusiaan dengan landasan nilai religiusitas dalam pendidikan dapat dijadikan sebagai proses pemanusiaan manusia dalam interaksi antar manusia dengan konteks dan tantangan yang terus berkembang. Pendidikan humanis berorientasi pada pengembangan manusia, menekankan nilai-nilai manusiawi, dan nilai-nilai kultural dalam pendidikan. Sasaran pokok pendidikan humanis adalah membentuk anggota keluarga, masyarakat, dan warga negara baik, yang memiliki jiwa demokratis, bertanggung jawab, memiliki harga diri, kreatif, rasional, objektif, tidak berprasangka, mawas diri terhadap perubahan dan pembaharuan serta mampu memanfaatkan waktu senggang secara efektif (Nurozi, 2016, p. 167). Pendidikan religius merupakan pendidikan yang mengajarkan nilai-nilai agama secara umum, apapun agamanya. Selain, pendidikan religius penuh dengan muatan nilai moral, pendidikan religius juga menjadi salah satu ruh pendidikan di Indonesia karena sesuai dengan falsafah pancasila sila pertama dan seluruh sila yang lain yang merupakan cerminan dari kepribadian bangsa Indonesia. Penjelasan tersebut menjadi sebuah landasan sebagai tujuan dari dilakukannya penelitian ini, yaitu untuk menjawab, bagaimanakah konsep ideal pendidikan humanis-religius? Bagaimana Pendidikan merespon dan menghadapi era revolusi industri 4.0? Bagaimana relevansi pendidikan humanisreligius dalam menghadapi era revolusi industri 4.0 ?

\section{METODE}

Penelitian ini menggunakan penelitian kualitatif. Hasil yang ingin diperoleh merupakan informasi berupa catatan dan data deskriptif yang terdapat di dalam teks yang diteliti (Mantra, 2008, p. 30). Pendekatannya menggunakan pendekatan studi literatur (literature review) atau studi pustaka (library research), yaitu menggunakan buku-buku dan literatur-literatur sebagai objek yang utama (Sutardi, 2007, p. 76). Data yang diperoleh dari hasil studi literatur kemudian dila-kukan analisis secara deskriptif. Metode analisis deskriptif memberikan gambaran dan keterangan yang secara jelas, objektif, sistematis, analitis dan kritis mengenai kajian reflektif pendidikan humanis-religius dalam menghadapi era revolusi industry 4.0.

Metode yang digunakan dalam penelitian kepustakaan adalah mengumpulkan data penelitian berupa data-data kepustakaan yang telah dipilih, dicari, disajikan dan dianalisis. Sumber data penelitian ini mencari data-data kepustakaan yang substansinya membutuhkan tindakan pengolahan secara filosofis dan teoritis. Studi pustaka di sini adalah studi pustaka tanpa disertai uji empirik (Muhadjir, 1998, p. 159). Data yang disajikan adalah data yang berbentuk kata yang memerlukan pengolahan supaya ringkas dan sistematis (Muhadjir, 1998, p. 29). Pengumpulan data yang dilakukan dalam penelitian ini adalah dengan mengumpulkan buku-buku ataupun berbagai artikel tentang pendidikan humanis-religius dan konsep era revolusi indusri 4.0. Kemudian data yang diperoleh, dipilih, disajikan, dan dianalisis, serta diolah secara sistematis untuk menghasilkan kajian yang kritis dan reflektif. Berikutnya, pengolahan data dilakukan tanpa menggunakan hitungan (statistik), namun melalui pemaparan suatu pemikiran, pendapat para ahli atau fenomena yang ada dalam kehidupan masyarakat (Moleong, 2009. p. 3). Pendapat para ahli dijabarkan melalui konsep 
ideal pendidikan humanis-religius dari tokoh pendidikan Ki Hajar Dewantara dan Pakar Pendidikan Islam Abdurrahman Mas'ud. Analisis berikutnya membahas tentang tantangan pendidikan di era revolusi industri 4.0 dan relevansi pendidikan humanis-religius dalam menghadapi era revolusi industri 4.0.

\section{HASIL DAN PEMBAHASAN}

Dasar Kebijakan Pendidikan Humanis-Religius

Pancasila sebagai dasar negara Republik Indonesia telah mengimplikasikan pendidikan humanis-religius pada sila kedua dan pertama. Sila Pertama, "Ketuhanan yang Maha Esa", mencerminkan jiwa bangsa Indonesia yang religius. Jiwa religiusitas sebagai sila pertama dalam pancasila diharapkan dapat menjadi landasan bagi pelaksanaan sila-sila yang lain. Sila kedua "kemanusiaan yang adil dan beradab", mencerminkan kehidupan bangsa Indonesia yang santun, menghargai hak orang lain. Sila ini mencerminkan kehidupan yang humanis (Hibana, Kuntoro, \& Sutrisno, 2015, p. 21). Pendidikan humanis-religius terkandung dalam fungsi pendidikan nasional. Undang-undang Nomor 20 Tahun 2003 Tentang Sistem Pendidikan Nasional Pasal 3 menyebutkan bahwa pendidikan nasional berfungsi untuk mengembangkan kemampuan dan membentuk watak serta peradaban bangsa yang bermartabat dalam rangka mencerdaskan kehidupan bangsa, bertujuan untuk berkembangnya potensi peserta didik agar menjadi manusia yang beriman dan bertakwa kepada Tuhan Yang Maha Esa, berakhlak mulia, sehat, berilmu, cakap, kreatif, mandiri, dan menjadi warga negara yang demokratis serta bertanggungjawab.

Undang-undang Sistem Pendidikan Nasional bab I, pasal I ayat (1) menyatakan bahwa pendidikan merupakan usaha sadar dan terencana untuk mengembangkan potensi siswa untuk memiliki kekuatan spiritual keagamaan, pengendalian diri, kepribadian, kecerdasan, akhlak mulia, serta ketrampilan yang diperlukan dirinya, masyarakat, bangsa, dan negara (Undang-Undang Sistem Pendidikan Nasional No. 20, 2003, p. 3). Lebih spesifik lagi, pada Undang-undang Sistem Nasional Pasal 30 menjelaskan bahwa pendidikan keagamaan berfungsi mempersiapkan peserta didik menjadi anggota masyarakat yang memahami dan mengamalkan nilai-nilai ajaran agamanya dan menjadi ahli ilmu agama. Lebih lanjut ditegaskan dalam Penjelasan Umum Peraturan Pemerintah Nomor 19 tahun 2005 tentang Standar Pendidikan Nasional Pasal 6 (ayat 1) butir a, bahwa peningkatan potensi spiritual dalam kelompok mata pelajaran agama dan akhlak mulia mencakup pengenalan, pemahaman, dan penanaman nilai-nilai keagamaan serta pengamalan nilai-nilai tersebut dalam kegiatan individual ataupun kolektif kemasyarakatan. Peningkatan potensi spiritual dapat dilakukan melalui optimalisasi berbagai potensi yang dimiliki manusia yang aktualisasinya mencerminkan harkat dan martabat sebagai mahluk Tuhan (Pasal 3 Undang-Undang Sistem Pendidikan Nasional). Fungsi pendidikan religius adalah untuk mempersiapkan peserta didik menjadi anggota masyarakat yang memahami dan mengamalkan nilai-nilai ajaran agamanya dan menjadi ahli ilmu agama.

Dari dasar kebijakan tersebut selama kebijakan-kebijakan masih diberlakukan, maka akan tetap dapat dijadikan landasan pendidikan humanis-religius untuk bisa relevan di semua kondisi dan keadaan, begitu pula pada saat ini ketika pendidikan harus menghadapi era revolusi industri 4.0. Pendidikan humanis-religius memiliki dasar yang kuat sebagai landasan untuk menjawab tantangan disrupsi perubahan zaman yang begitu cepat dan tak terkendali.

\section{Konsep Pendidikan Humanis-Religius Ki Hajar Dewantara}

Konsep pendidikan menurut Ki Hajar Dewantara sesuai dengan konsep pendidikan humanis. Pendidikan humanis adalah pendidikan yang mampu memperkenalkan apresiasinya yang tinggi kepada manusia sebagai makhluk Tuhan yang mulia dan bebas dalam batas-batas eksistensinya yang hakiki sebagai khalifatullah. Dengan demikian, pendidikan humanis bertujuan membentuk insan manusia yang memiliki kesadaran, kebebasan, dan tanggung jawab sebagai insan manusia individual, tetapi tetap bertanggung jawab terhadap lingkungan masyarakatnya (Makin, 2007, p. 23). Menurutnya, manusia memiliki daya jiwa yaitu: cipta, rasa, dan karsa. Pengembangan manusia seutuhnya menuntut pengembangan semua daya secara seimbang. Pendidikan yang hanya menekankan pada 
aspek intelektual saja akan menjauhkan peserta didik dari masyarakatnya, sedangkan pendidikan yang tidak mengembangkan aspek intelektual maka pendidikan akan menjadi stagnan, menghambat pembangunan, sehingga tidak dapat berkembang mengikuti kemajuan jaman.

Dari tiga daya jiwa tersebut yang menyebabkan manusia megerti dan menyadari akan keberadaan dirinya yang merdeka, dapat mengatur, menentukan, dan menguasai dirinya, memiliki budi dan kehendak, memiliki dorongan untuk mengembangkan pribadinya menjadi lebih baik dan lebih sempurna (Dewantara, 2004). Menjadi manusia merdeka merupakan tujuan pendidikan Ki Hajar Dewantara, merdeka baik secara fisik, mental, dan kerohanian. Kemerdekaan pribadi dibatasi oleh tertib damai kehidupan bersama, dan ini mendukung sikap-sikap seperti keselarasan, kekeluargaan, musyawarah, toleransi, kebersamaan, demokrasi, tanggungjawab, dan disiplin. Ki Hajar Dewantara mengatakan bahwa syarat untuk menciptakan pendidikan yang efektif adalah seorang guru harus berperilaku humanis. Pendidikan yang humanis sejajar dengan pendidikan efektif, artinya pendidikan yang berpusat pada siswa yang sesuai dengan minat dan kebutuhan siswa. Guru menghormati dan menerima siswa sebagaimana adanya dan bertugas membantu siswa untuk menemukan, mengembangkan dan mencoba mempraktikkan kemampuan-kemampuan yang mereka miliki (The learners-centered teaching) agar menjadi manusia yang menghormati dan menghargai orang lain.

Untuk memperkuat konsep pendidikan humanis-religius $\mathrm{Ki}$ Hajar Dewantara mengemukakan lima asas yang dikenal dengan sebutan "panca darma", yaitu: 1.) Asas kebangsaan. Asas kebangsaan tidak boleh bertentangan dengan kemanusiaan, karena asas ini mengandung rasa satu dengan bangsa sendiri, rasa satu dalam suka dan duka, rasa satu dalam kehendak menuju kepada kebahagiaan lahir dan batin seluruh bangsa serta mampu membina pergaulan dan menjalin kerjasama dengan bangsa lain; 2.) Asas kemanusiaan. Dasar kemanusiaan berusaha mengembangkan sifat-sifat luhur manusia. Hidup bersama atas dasar kegotongroyongan dan saling mengasihi dan saling mengasuh dan membimbing agar bisa menjadi pribadi yang baik; 3.) Asas kodrat alam. Asas ini yang dimanfaatkan untuk bisa mengembangkan segenap bakat, potensi dan kemungkinan yang ada pada diri manusia sebagai anugrah dari Tuhan secara kodrati; 4.) Asas kemerdekaan. Asas yang didasarkan pada sikap pendidik sebagai pimpinan untuk menjalankan sikap laku "tutwuri handayani" yang berarti mengikuti dari belakang dan memberikan pengaruh. Mengikuti dari belakang bermakna memberikan kebebasan kepada anak didik tanpa meninggalkan pengawasan; dan 5.) Asas kebudayaan. Asas kebudayaan dipakai untuk membimbing peserta didik agar tetap menghargai serta mengembangkan kebudayaan sendiri. Kebudayaan sebagai buah budi dan hasil perjuangan manusia terhadap kekuasaan alam sebagai tanda kesanggupannya untuk mengatasi berbagai rintangan dan hambatan dalam kehidupan sehari-hari untuk mendapatkan keselamatan dan kebahagiaan hidup bersama.

Apabila dilihat dari sudut pandang isinya, pendidikan yang digagas oleh Ki Hadjar Dewantara memiliki kriteria-kriteria yang secara eksplisit mengandung enam unsur, yaitu: 1.) Pendidikan kebebasan (merdeka); 2.) Pendidikan kemanusiaan (humanisme); 3.) Pendidikan spiritual (kodrat alam); 4.) Pendidikan budi pekerti; 5.) Pendidikan sosial (kekeluargaan); dan 6.) Pendidikan kepemimpinan (tut wuri handayani) (Muthoifin, 2015). Enam unsur tersebut merupakan penjabaran dari konsep pendidikan humanis-religius yang didukung oleh pendidikan kepemimpinan yang mampu mengarahkan pendidikan kepada perubahan yang lebih baik dalam kondisi era apapun, termasuka dalam era revolusi industry 4.0 .

\section{Konsep Pendidikan Humanis-Religius Abdurrahman Mas'ud}

Pemikiran konsep pendidikan Abdurrahman Mas'ud menawarkan tentang paradigma baru mengenai konsep pendidikan humanis-religius. Abdurrahman merupakan tokoh pemikiran pendidikan Islam kontemporer yang pernah menjabat sebagai rector Universitas Sains Al-Qur'an dan berlanjut diberi amanah sebagai pejabat kepala Badan Penelitian dan Pengembangan, serta Pendidikan dan Pelatihan Kementerian Agama Republik Indonesia. Guru besar ilmu sejarah dan kebudayaan Islam yang disandangnya pada tahun 2004 membuatnya konsen dalam perumusan paradigma baru pendidikan Islam yang humanis-religius. Hal ini, terbukti pada beberapa karya tulisnya yang sering membahas tentang pendidikan humanis-religius.

Menurut Abdurrahman Mas'ud, pendidikan humanis-religius adalah pendidikan yang mengajarkan tentang keseimbangan antara ilahiyyah dan insaniyah. Secara spesifik, pemikirannya khusus menyoalkan tentang pendidikan Islam yang kurang menekankan pada aspek sosial kemanu- 
siaan. Pernyataan ini berdasarkan fakta riil dari hasil pendidikan yang lebih terlihat berat di salah satu sisi saja. Misalnya, keberagamaan yang hanya menampakkan kesalehan ritual tapi meninggalkan kesalehan sosial, ataupun sebaliknya. Implikasinya, terlihat pada realitas sosial yang hanya dihiasi dengan budaya ritualistik tanpa adanya nilai-nilai spiritual yang berorientasi pada nilai-nilai kemanusiaan (Mas'ud, 2011).

Sebenarnya, kata humanis-religius mengandung dua konsep pendidikan yang terintegrasi yaitu pendidikan humanis dan pendidikan religius. Pengintegrasian dua konsep pendidikan ini bertujuan untuk dapat membangun sistem pendidikan yang terintegrasi dari keduanya atau mengurangi kelemahannya (Suyatno, 2012, p. 30). Humanis dalam konteks pendidikan dimaknai sebagai proses pendidikan yang lebih menghubungkan dua aspek potensi manusia yaitu sebagai makhluk sosial dan makhluk religius (abdullah dan khalifatullah). Sebagai individu, manusia diberi kesempatan sebebas-bebasnya oleh Tuhan untuk bisa mengembangkan segala potensi-potensi yang dimilikinya. Humanis juga lebih dimaknai sebagai kekuatan atau potensi individu untuk mengukur dan mencapai ranah ke-Tuhanan (religius) dan penyelesaian permasalahan-permasalahan sosial (humanis). Namun, kebebasan atau kemerdekaan individu dalam pendidikan humanis dibatasi oleh nilai-nilai Islam. Nilai Islam itulah yang diharapkan menjadi pendorong perwujudan nilai-nilai kemanusiaan.

Pada konsep religius, pengertian dari manusia religius adalah orang yang mampu menerjemahkan nilai-nilai keagamaan dalam kehidupan sehari-hari. Pada kenyataannya, berbagai macam budaya atau kultur yang bernuansa agama yang ada tidak mengandung nilai spiritual yang berpihak pada kemanusiaan. Sentimen keberagamaan yang tinggi pada saat dihubungkan dengan persoalan yang mengatasnamakan Tuhan, tetapi melemah ketika persoalan yang dihadapi adalah persoalan kemanusiaan, seperti korupsi, ketidakadilan, dan lain sebagainya. Hal ini dianalogikan pada gugurnya pahala orang yang beribadah haji karena lupa akan esensi pengorbanan dalam Islam. Begitu pula dengan analogi orang yang melakukan shalat, puasa, zakat yang sia-sia karena mengabaikan ajaran hak asasi manusia dan keadilan dalam Islam. Maksudnya adalah orang-orang saleh bisa saja akan masuk neraka karena dosa-dosanya yang mengabaikan permasalahan sosial disekitarnya. Sama juga dengan orang yang rajin melakukan shalat, zakat, puasa tetapi merasa bahagia disaat orang lain tertimpa duka (Mas'ud, 2002, p. 141).

Abdurrahman Mas'ud menilai urgensi humanisme religius diperkenalkan karena beberapa alasan untuk mendobrak paradigma lama yang sampai saat ini masih menjadi fenomena sosial, diantaranya, yaitu: 1.) Keberagamaan yang cenderung menekankan hubungan vertikal dan kesemarakan ritual saja; 2.) Kesalehan sosial yang masih jauh dari orientasi masyarakat; 3.) Potensi peserta didik belum dikembangkan secara proporsional karena pendidikan belum berorientasi pada pembangunan sumber daya manusia atau belum individual oriented; dan 4.) Rendahnya kemandirian anak didik dan tanggung jawab (responsibility) dalam pencapaian dunia pendidikan Islam. Untuk mengatasi fenomena tersebut, pendidikan humanis-religius mengambil peran yang penting. Abdurrahman Mas'ud menawarkan konsep humanism religius dengan lima aspek yang perlu dikembangkan dalam dunia pendidikan Islam, yaitu meliputi common sense, individualisme menuju kemandirian, thirst of knowledge, pendidikan pluralisme, kontekstualisme yang lebih mementingkan fungsi dari simbol, dan keseimbangan antara reward and punishment. Diharapkan enam aspek tersebut dapat mengatasi berbagai permasalahan umat Islam pada umumnya dan dunia pendidikan pada khususnya.

Oleh karenanya, dapat disimpulkan bahwa Abdurrahman Mas'ud mendefinisikan pendidikan humanis-religius sebagai suatu cara pandang agama yang menempatkan manusia sebagai manusia dan suatu usaha humanisasi ilmu-ilmu pengetahuan dengan penuh keimanan yang disertai hubungan manusia dengan Allah SWT dan sesama manusia atau hablun min Allah dan hablun min al-nas (Mas'ud, 2001, p. 92).

Tantangan Pendidikan di Era Revolusi Industri 4.0

Disrupsi mendorong terjadinya digitalisasi pada sistem pendidikan. Munculnya inovasi aplikasi teknologi seperti Uber atau Gojek akan menginspirasi lahirnya aplikasi sejenis di bidang pendidikan, misalnya MOOC, singkatan dari Massive Open Online Course serta AI (Artificial Intelligence). MOOC adalah inovasi pembelajaran daring yang dirancang terbuka, dapat saling ber- 
bagi dan saling terhubung atau berjejaring satu sama lain. Prinsip ini menandai dimulainya demokratisasi pengetahuan yang menciptakan kesempatan bagi pendidikan untuk memanfaatkan dunia teknologi dengan produktif. Sedangkan AI adalah mesin kecerdasan buatan yang dirancang untuk melakukan pekerjaan yang spesifik dalam membantu keseharian manusia. Di bidang pendidikan, AI akan membantu pembelajaran yang bersifat individual, sebab AI mampu melakukan pencarian informasi yang diinginkan sekaligus menyajikannya dengan cepat, akurat, dan interaktif. Baik MOOC maupun AI akan mengacak-acak metode pendidikan lama.

Kegiatan belajar-mengajar akan berubah total. Ruang kelas mengalami evolusi dengan pola pembelajaran digital yang memberikan pengalaman pembelajaran yang lebih kreatif, partisipatif, beragam, dan menyeluruh. Evolusi pembelajaran yang ditawarkan oleh MOOC dan AI akan memunculkan pertanyaan kritis, "Masih relevankah peran guru ke depan?" Chief Executive Officer The Hub Edu, Tiffany Reiss berpendapat bahwa guru memiliki peran penting dalam melakukan kontekstualisasi informasi serta bimbingan terhadap siswa dalam penggunaan praktis diskusi daring. Jack Ma, pendiri Alibaba, perusahaan transaksi daring terbesar di dunia juga mengatakan bahwa fungsi guru pada era digital ini berbeda dibandingkan guru masa lalu. Pada masa sekarang ini guru tidak mungkin mampu bersaing dengan mesin dalam hal melaksanakan pekerjaan hafalan, hitungan, hingga pencarian sumber informasi. Mesin jauh lebih cerdas, berpengetahuan, dan efektif dibandingkan dengan manusia, karena tidak pernah lelah dalam melaksanakan tugasnya yang telah tersistem. Oleh karena itu, fungsi guru bergeser lebih pada mengajarkan nilai-nilai etika, budaya, kebijaksanaan, pengalaman, hingga empati sosial, karena nilai-nilai itulah yang tidak dapat diajarkan oleh mesin. Guru perlu untuk memulai mengubah cara mereka mengajar, meninggalkan cara-cara lamanya serta fleksibel dalam memahami hal-hal baru dengan lebih cepat.

Teknologi digital dapat membantu guru belajar lebih cepat dan lebih efektif untuk berubah dan berkembang. Mereka akan lebih cakap mengubah pelajaran yang membosankan dan tidak inovatif menjadi pembelajaran multistimulan, sehingga menjadi lebih menyenangkan dan menarik perhatian peserta didik dalam mengikuti kegiatan belajar mengajar. Pertanyaannya adalah apakah guru-guru saat ini telah disiapkan untuk menghadapi perubahan peran ini? Ini bukan hanya persoalan mengganti kelas tatap muka konvensional menjadi pembelajaran daring, namun yang lebih penting adalah revolusi peran guru sebagai sumber belajar atau pemberi pengetahuan menjadi mentor, fasilitator, motivator, bahkan inspirator untuk mengembangkan imajinasi, kreativitas, karakter, serta team work siswa yang dibutuhkan di masa depan.

Relevansi Pendidikan Humanis-Religius dalam Menghadapi Era Revolusi Industri 4.0

Banyak solusi telah dilakukan untuk menghadapi keadaan disrupsi diantaranya ada dua hal yang penting, yaitu memberikan penyadaran keadaan disrupsi, meningkatkan aspek humanis pada pendidikan, dan mengembangkan nilai religius. Masa disrupsi tak bisa lagi dihindari, masa ini akan terus berlangsung dan menuntut adanya adaptasi yang cepat pada masyarakat. Untuk mengatasi masalah ini maka upaya penyadaran kepada masyarakat harus terus dilakukan (Clarke, Murphy, \& Lorenzoni, 2018). Upaya yang dilakukan harus dapat memberikan penjelasan bahwa disrupsi dapat memberikan peluang positif, namun dapat juga memberikan peluang negatif. Pemberian informasi yang jelas kepada masyarakat diharapkan dapat menyadarkan untuk segera beradaptasi dengan keadaan. Tema kesadaran yang terpenting adalah menumbuhkan harapan bahwa dengan potensi yang dimiliki, masyarakat akan tetap mempunyai peluang yang sama untuk maju, berkarakter dan meningkatkan kesejahteraannya.

Selain meningkatkan kesadaran, upaya lain yang telah dilakukan adalah mengembangakan nilai-nilai humanis dalam lingkungan masyarakat dan lingkungan sekolah. Suasana dan sikap individualis harus dikembalikan kepada keadaan yang humanis. Keadaan dan perkembangan teknologi jangan sampai dibiarkan menganggu dan merusak tata nilai yang ada di masyarakat, sekolah serta lingkungan lainnya. Upaya mengembalikan nilai ditengah pesatnya perkembangan teknologi dan industri akan menjamin manusia tetap mempunyai nilai-nilai kemanusiaan yang harus tetap dijunjung tinggi oleh masyarakat, serta menjamin kelangsungan kehidupan bermasyarakat yang baik. Nilai-nilai humanis yang telah ada dan tidak bertentangan dengan norma-norma agama sebaiknya dipertahankan sebagai acuan dalam mengembalikan nilai-nilai dan perilaku masyarakat. Upaya ini 
diharapkan dapat menempatkan nilai-nilai kemanusiaan sebagai pertimbangan dalam mengembangkan teknologi dan industri.

Selain itu, alternatif cara lain yang lebih teknis dalam menghadapi revolusi industri 4.0, yaitu pertama, menyiapkan pelaksanaan pendidikan yang link and match antara sumber daya manusia dan kebutuhan zaman di era revolusi industry 4.0. Kedua, selain menyiapkan pendidikan yang link and match, sumber daya manusia yang disiapkan juga harus dibekali dengan pendidikan nilai-nilai kemanusiaan dan nilai-nilai keagamaan, sebab ketika ilmu-ilmu eksakta berperan dalam pengembangan teknologi secara empiris, maka pendidikan humanis-religius tetap berperan dalam menjaga kualitas manusianya (software/users). Jika hal ini dapat terwujud, maka kemajuan teknologi sebagai anak kandung ilmu pengetahuan dapat memberikan dampak positif bagi peradaban manusia itu sendiri.

\section{SIMPULAN}

Dari hasil dan pembahasan pada penelitian ini dapat disimpulkan bahwa pendidikan humanis-religius memiliki relevansi dalam menghadapi era apapun, termasuk era revolusi industri 4.0. Seberapa canggih teknologi yang dihasilkan manusia, manusia tidak boleh kehilangan sisi kemanusiaannya. Konsep pendidikan Ki Hajar Dewantara melalui panca darma dan enam unsur pendidikannya dapat dijadikan pijakan pendidikan dalam melakukan berbagai pertimbangan untuk menghadapi perubahan dan kemajuan teknologi komunikasi di era revolusi industri 4.0 agar hasil dari kerja teknologi dapat dimanfaatkan sebaik-baiknya oleh manusia intelektual terdidik untuk kemaslahatan bersama. Begitu pula dengan pemikiran pendidikan humanis-religius dari Abdurrahman Mas'ud yang menawarkan konsep humanisme religius dengan lima aspek yang perlu dikembangkan dalam dunia pendidikan Islam, yaitu meliputi common sense, individualisme menuju kemandirian, thirst of knowledge, pendidikan pluralisme, kontekstualisme yang lebih mementingkan fungsi dari pada simbol, dan keseimbangan antara reward and punishment.

Pendidikan merespon dan menghadapi era revolusi industri 4.0 dengan merevolusi peran guru sebagai sumber belajar atau pemberi pengetahuan dengan menjadi mentor, fasilitator, motivator, bahkan inspirator untuk mengembangkan imajinasi, kreativitas, karakter, serta teamwork siswa yang dibutuhkan di masa depan. Teknologi digital dapat membantu guru belajar lebih cepat dan lebih efektif untuk berubah dan berkembang. Mereka akan lebih cakap mengubah pelajaran yang membosankan dan tidak inovatif menjadi pembelajaran multi-stimulan sehingga menjadi lebih menyenangkan dan menarik. Relevansi pendidikan humanis-religius dalam menghadapi era revolusi industri 4.0 yaitu: 1.) Menyiapkan pelaksanaan pendidikan yang link and match antara sumber daya manusia dan kebutuhan zaman di era revolusi industri; dan 2.) Menyiapkan dan membekali sumber daya alam dengan pendidikan nilai-nilai kemanusiaan dan nilai-nilai keagamaan.

\section{DAFTAR PUSTAKA}

Clarke, D., Murphy, C., \& Lorenzoni, I. (2018). Place attachment, disruption, and transformative adaptation. Journal of Environmental Psychology, 55, 81-89. Doi: https://doi.org/10.1016/j.jenvp.2017.12.006

Dewantara, K. H. (2004). Bagian Pertama: Pendidikan (Cetakan ke-3). Yogyakarta: Majelis Luhur Persatuan Tamansiswa (MLPTS).

Guha, M. (2013). Education in a Tagorean perspective. International Journal of Humanities and Social Science Invention, 2(12), 35-41.

Hibana, H., Kuntoro, S. A., \& Sutrisno, S. (2015). Pengembangan pendidikan humanis religius di madrasah. Jurnal Pembangunan Pendidikan: Fondasi dan Aplikasi, 3(1), 19-30. Doi: https://doi.org/10.21831/jppfa.v3i1.5922

Mantra, B. I. (2008). Filsafat penelitian \& metode peneliian sosial. Yogyakarta: Pustaka Pelajar.

Mas'ud, A. (2002). Menggagas format pendidikan nondikotomik: Humanisme religius sebagai paradigma pendidikan Islam. Yogyakarta. Gama Media. 
34 - Jurnal Pembangunan Pendidikan: Fondasi dan Aplikasi

Mas'ud, A. (2003). Menuju paradigma Islam humanis. Yogyakarta: Gama Media.

Mas'ud, A. (2006). Dari haramain ke nusantara: Jejak intelektual arsitek pesantren. Jakarta: Kencana Prenada Media.

Mas'ud, A. (2011) Humanisme religius sebagai paradigma pendidikan Islam, Jurnal Penelitian Walisongo, $17(1)$.

Moleong, L. J. (2009). Metodologi penelitian kualitatif. Bandung: Remaja Rosdakarya Offset.

Muhadjir, H. N. (1998). Filsafat ilmu: Telaah sistematis fungsional komparatif. Rake Sarasin.

Muthoifin, M. (2015). Pemikiran pendidikan multikultural Ki Hadjar Dewantara. Intizar: Jurnal Kajian Keislaman dan Kemasyarakatan, 21(2), 299-320.

Nurozi, A. (2016). Relevansi dan integrasi konsep pendidikan Islam humanis religius dalam sistem pendidikan nasional. Jurnal eL-Tarbawi, 9(2), 163-174. Doi: https://doi.org/10.20885/tarbawi.vol9iss2.art5

Presiden Republik Indonesia. (2003). Undang-Undang Nomor 20, Tahun 2003, Tentang Sistem Pendidikan Nasional.

Saksono, G. I. (2008). Pendidikan yang memerdekakan siswa. Yogyakarta: Rumah Belajar Yabinkas.

Samuel, F. A. (2010). Tagore's vision of international education: Relevance and implications for today. The Educational Forum Journal, 75(4), 347-356. Doi: https://doi.org/10.1080/00131725.2010.507103

Samuel, F. A. (2011). Educational visions from two continents: What Tagore adds to the Deweyan perspective. Educational Philosophy And Theory, 43(10), 1161-1174. Doi: https://doi.org/10.1111/j.1469-5812.2010.00648.x

Subasman, I. (2019). Peran evaluasi pendidikan pada era disrupsi. Doi: https://doi.org/10.31227/osf.io/z9vny

Sukartono, S. (2018). Revolusi industri 4.0 dan dampaknya terhadap pendidikan di Indonesia. Retrieved from http://pgsd.ums.ac.id/wp-content/uploads/sites/73/2018/12/MateriSukartono.pdf

Sutardi, T. (2007). Antropologi: Mengungkap keragaman budaya. Grafindo Media Pratama.

Suyatno, S. (2012). Pendidikan karakter dalam perspektif pendidikan humanis religious. Jurnal Pendidikan Agama Islam, 9(1). 